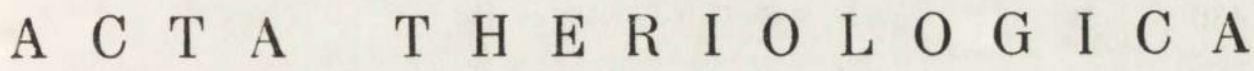 \\ VOL. XIII, 26: 435-445. \\ BIAŁOWIEŻA \\ $30 . X .1968$
}

\author{
Kazimierz PETR USE W I C Z, Roman A N D Z E J E W K I, \\ Gabriela B U J A LSKA \& Joanna G LIW I C Z
}

\section{Productivity Investigation of an Island Population oi Clethrionomys glareolus (Schreber, 1780). IV. Production*)}

[With 2 Figs. \& 3 Tables]

\begin{abstract}
Calculation was made, on the basis of individual growth and empirical survivorship curves, of the productivity achieved by a population of C. glareolus during the course of one year $(P=11,429 \mathrm{~g}$ live weight/ /year/population). Production achieved during the reproduction season was $P=10.263 \mathrm{~g}$ and during the winter $P=1166 \mathrm{~g}$. During the reproduction period the value was determined of the production of young achieved at the mother's expense (up to the 21st day of life) $-P_{r}=$ $5848 \mathrm{~g}$ and value of production due to growth $-P_{\mathrm{g}}=5581 \mathrm{~g}$.
\end{abstract}

\section{INTRODUCTION}

The subject of the present study is an attempt at estimating the production of a population of Clethrionomys glareolus ( $\mathrm{S} \mathrm{chreber}$, 1780 ), with particular emphasis on the ratio of production due to reproduction $\left(P_{r}\right)$ and production due to growth $\left(P_{g}\right)$, and the productivity of the generations (cohorts) distinguished in different phenological periods.

Calculation of production was carried out for a free-living population of $C$. glareolus inhabiting an island in Lake Bełdany in northern Poland (Mazurian lake district). This island, 4 ha in area, covered by mixed forest, was a natural habitat of $C$. glareolus (for detailed description of the habitat see $\mathrm{Traczyk}, 1965$, and G liwicz et al., 1968).

* This study was carried out under the Small Mammal Project of the International Biological Programme in Poland.

[435] 


\section{MATERIAL}

Investigation of settlement of the island was carried out seven times by means of the method giving a general census of the whole trappable part of the population, recording: date, sex and weight, and marking each individual with a separate number. Vaginal smears were taken from adult females. These censuses made it possible to mark the whole trappable part of the population in November 1965 and April 1966. The newly-registered individuals (not marked) could be considered as having been born after the last census and thus it was possible to define the period in which they had been born. This permitted of distinguishing 5 cohorts: $K_{0}$ - overwintered animals of unknown age, $K_{1}$ - early spring cohort with mean date of birth May 5th (from April 1st to May 26th), $K_{2}-$ early summer cohort with mean date of birth June 19th (from May 27th to July 10th), $K_{3}$ - summer cohort, mean date of birth August 2nd (from July 11th to August 28th), $K_{4}$ - autumn cohort, mean date of birth Sept. 10th (from August 29 th to October 1st 1966). An individual growth curve (B ujalska \& Gliwicz, 1968) was drawn for each of these cohorts, and also survivorship curve (Gliwicz, Andrzejewski, Bujalska \& Petrusewicz, 1968).

The survivorship curve for trappable part of the population was drawn on the basis of empirical data-numbers of the given cohort at the time of the census (see Fig. 1 presenting the survivorship curve of cohort $K_{1}$ ). We assume that this part of the survivorship curve gives a very accurate representation of the real situation (G liwicz et al., 1968). The survivorship curve for untrapped individuals (up to approx. 43 days) was based on: (1) calculated number of animals born established by means of the formula $v_{r}=\left(\bar{N}_{p} \cdot T \cdot L\right): t_{p}$, where $\bar{N}_{p}-$ mean numbers of pregnant females in this period $T, L-$ size of litter, $t_{p}-$ duration of pregnancy (22 days); (2) empirically defined numbers of registered individuals during the first census from the number born during the reproduction period preceding this census (B ujalska, Andrzejewski \& Petrusewicz, 1968); (3) calculation of the mean balanced date of birth (day which divided the number born into two equal halves), and (4) the assumption that from the mean date of birth, when there were $v_{r}$ of them, disappearance up to the time of registration took the form of an exponential curve ${ }^{1}$ ).

Individual growth curve was drawn for the trappable part of the population from empirical field data (weights of individuals of known mean age). The shaje of the curve from the individual growth was accepted for the untrapped part of the population, for C. glareolus in captivity (D r o ż d $\dot{z}, 1965)$, extrapolating (lowering) the weight in proportion to the mean weight on the day of capture and weight on the same day in captivity (B ujalska \& Gliwicz, 1968).

\section{PRINCIPLES FOR CALCULATING PRODUCTION $(P)$}

Calculation of production was based on data obtained from the survivorship curve and individual growth curve (Fig. 1). Production was estimated separately for each cohort. Calculation was made for each section of time of the production of those animals which were eliminated, multiplying the number of eliminated animals $\left(\Delta N_{T},=\right.$ $=N_{o}-N_{T}$ ) by weight increase to the middle of time $T^{\prime}$ : (silent ass-

${ }^{1}$ ) Individuals from cohort $K_{4}$ only up to the 21 st day of life. 
umption: an average individual survived to half the time $T^{\prime}$; after this we add the production of those animals which survived: the product of the number at the end of the section $\left(N_{T}\right)$ times weight increase for time $T\left(\Delta W=W_{T}-W_{o}\right)$. As a result we obtain production for time $T^{\prime}:$

$$
P_{T^{\prime}}=\Delta N_{T^{\prime}} \cdot \Delta \mathrm{W}_{T^{\prime} / 2}+N_{T} \cdot \Delta \mathrm{W}
$$

Next, totalling the production of all $\mathrm{K}$ sections, we obtain realized body growth $\left(P_{g}\right)$ for time $T$ :

$$
P_{T}=\sum_{i=1}^{\mathrm{i}=\mathrm{K}}\left(\Delta N_{T^{\prime}} \cdot \Delta \mathrm{W}_{T^{\prime} / 2}+N_{T} \cdot \Delta \mathrm{W}\right)_{i}
$$

In order to obtain complete production for the period from birth to the above sum it is necessary to add the biomass of newborn animals.

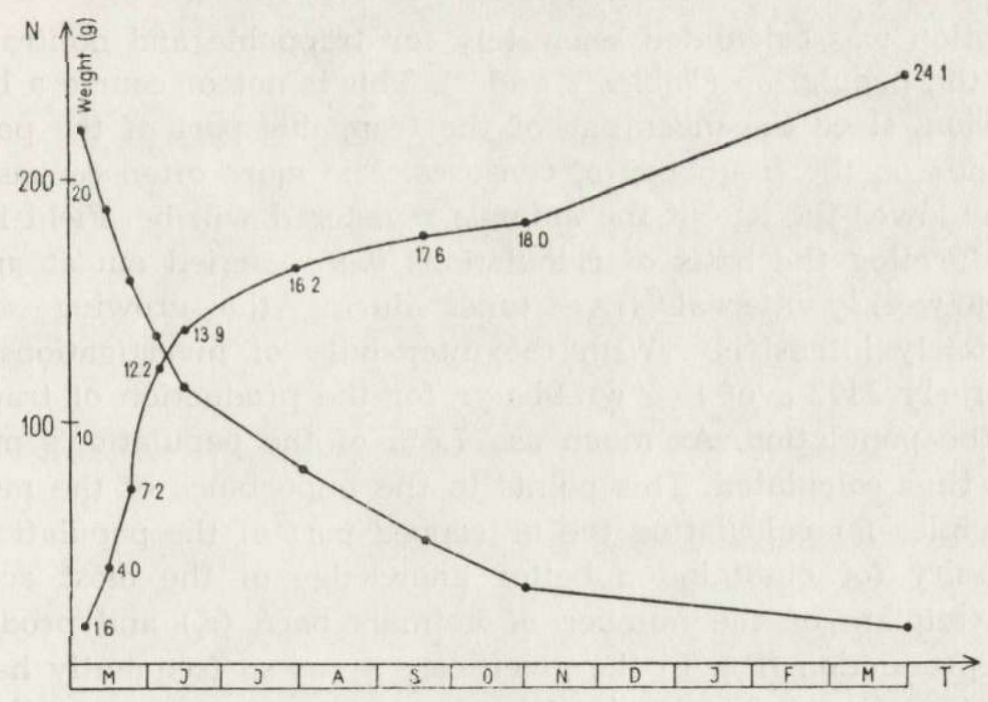

Fig. 1. Growth curve and survivorship curve of $K_{1}$ cohort of a population of Clethrionomys glareolus from birth up to 12 months of life.

$\mathrm{R}$ e mark 1 . Weight increase to half period $T^{\prime}$ is not always equal to half the increase for the whole period $T^{\prime}$, since the individual growth curve is not a straight line. It is only in the later periods when weight increase was very slight that there were cases when $\Delta W_{T^{\prime 2}}=\frac{1}{2} \Delta W_{T}$.

$\mathrm{R}$ e $\mathrm{mark} 2$. For the trappable part of the population the loss of the number of individuals in the cohort was taken as forming a straight line (since no information was available on what had happened in the meantime). For the untrapped part of the population calculation was made of how many individuals there would be on a given day $T$, 
according to formula $N_{T}=N_{r} \cdot e^{-\mu T}, \mu$ being obtained having the number born, number registered from among those born and the time from mean day of birth to the census. Calculation was made for the trappable part of the population for the sections described by days of censuses as April 29th, June 16th, July 31st, September 18th, November 2nd or dates describing phenological periods: reproduction began April 1st, the census was April 29th, and therefore the curve of elimination of overwintered animals $\left(K_{0}\right)$ was extrapolated up to April 1 st; in the same way we defined the numbers of the cohorts on October 1st, which was accepted as the end of the reproduction period.

\section{DISCUSSION OF RESULTS}

Production was calculated separately for trappable and nontrappable parts of the population (Tables 1 and 2). This is not of course a biological division, since the mean age of the trappable part of the population depends on the frequency of censuses. The more often censuses are made, the lower the age of the animals registered will be. Field investigations forming the basis of calculations were carried out at approximately 6 weekly intervals (five times during the growing season), that is, fairly intensively. With the intensivity of investigations there were scarcely $2302 \mathrm{~g}$ of live wt/4 ha/yr for the production of trappable part of the population. As much as $77.6 \%$ of the population's production was thus calculated. This points to the importance of the methods and principles for calculating the untrapped part of the population and the necessity for obtaining a better knowledge of the most accurate possible estimate of the number of animals born $\left(v_{r}\right)$ and production due to reproduction $\left(P_{r}\right)$. In the given case - as so frequently happens in ecology - we can foresee the direction of the error in our estimation of the number born $\left(v_{r}\right)$ but we do not yet know how to assess the extent of the error. We realize that the number born $\left(v_{r}\right)$ assessed by the formula:

$$
v_{r}=\frac{\bar{N} p \cdot T \cdot L}{t_{p}}=\frac{\bar{N} \cdot s \cdot f \cdot T \cdot L}{t_{p}}
$$

overestimates the number born since it does not completely take into account the mortality of pregnant females (partially taken into account by taking $\bar{N}_{p}$ - mean numbers of pregnant females as a basis). We do not, however, yet know how to estimate the extent of this observation.

The total value of yearly production $P=11429 \mathrm{~g}$ live wt $/ 4 \mathrm{ha} / \mathrm{yr}$. Its energy value was calculated accepting after Górecki (1967) the 
mean annual energy equivalent of $1 \mathrm{~g}$ of biomass of adult C. glareolus as 1454 and $1030 \mathrm{cal} / \mathrm{g}$ for newborn animals. We obtained $P=0.4$ $\mathrm{kcal} / \mathrm{m}^{2} / \mathrm{yr}$. This value can be compared with selected values of production taken from Wi egert \& Evans (1967) which, in kcal/ $/ \mathrm{m}^{2} / \mathrm{yr}$ are:

Old field mouse
Deer mice
Elephant population
Orthoptera
Grasshoppers

0.12 Old field, South Caroline, USA

0.01 Old field, South Michigan, USA

0.34 Uganda

4.00 Old field, South Caroline, USA

11.00 Coastal Salt Marsh, Georgia, USA.

It can only be said that the results we obtained are high, but are distributed in an order of already known values. We fully realize the hitherto limited possibilities of such comparison on account of the considerable difference in accuracy of empirical data and differences in methods of calculating production.

Production is realized by reproduction $\left(P_{r}\right)$ and growth of individuals $\left(P_{g}\right)$. These values, interesting from the point of view of ecology and evolution, and in particular their proportions, have not often formed the object of investigations. From the literature available (cf. P e truse w i c z \& W a l k ow a, 1968) we know that these values were defined for an individual of Oniscus asellus ( $\mathrm{Philipson}, 1967)$ and for Tribolium castaneum (Klekowski, Prus \& Żyromska- $\mathrm{R} \mathrm{u} \mathrm{d} \mathrm{z} \mathrm{k} \mathrm{a,} \mathrm{1967)} \mathrm{and} \mathrm{for} \mathrm{a} \mathrm{population} \mathrm{of} \mathrm{white} \mathrm{laboratory} \mathrm{mice} \mathrm{(W} \mathrm{a} \mathrm{l-}$ kowa, 1967; P etrus ewicz \& Walkowa, 1968).

With mammals a difficulty arises as to what to consider as production due to reproduction: whether the weight at the time of birth, or, as Petrusewicz (1967) and Petrusewicz \& W alkowa (1968) suggest, the whole production from birth to the end of nursing. It seems to us that this latter value should be treated in the case of mammals as production due to reproduction $\left(P_{r}\right)$ since this is production realized at the mother's expense. A further question then arises: to what day should the production of suckling animals be treated as production due to reproduction $\left(P_{r}\right)$ : to the end of the nursing period, until the beginning of independent feeding, or for some intermediate date expressing how much has been produced at the mother's expense. Our material did not make it possible to define either the start of independent feeding or the end of nursing. We therefore accepted the age of 21 days given as the end of nursing by Kowalski (1964) and confirmed by our observations (the youngest animals caught were, judged by weight and growth curve, about 21 days old). Production up to the 21st day of life was therefore considered as production due to reproduction $\left(P_{r}\right)$. 


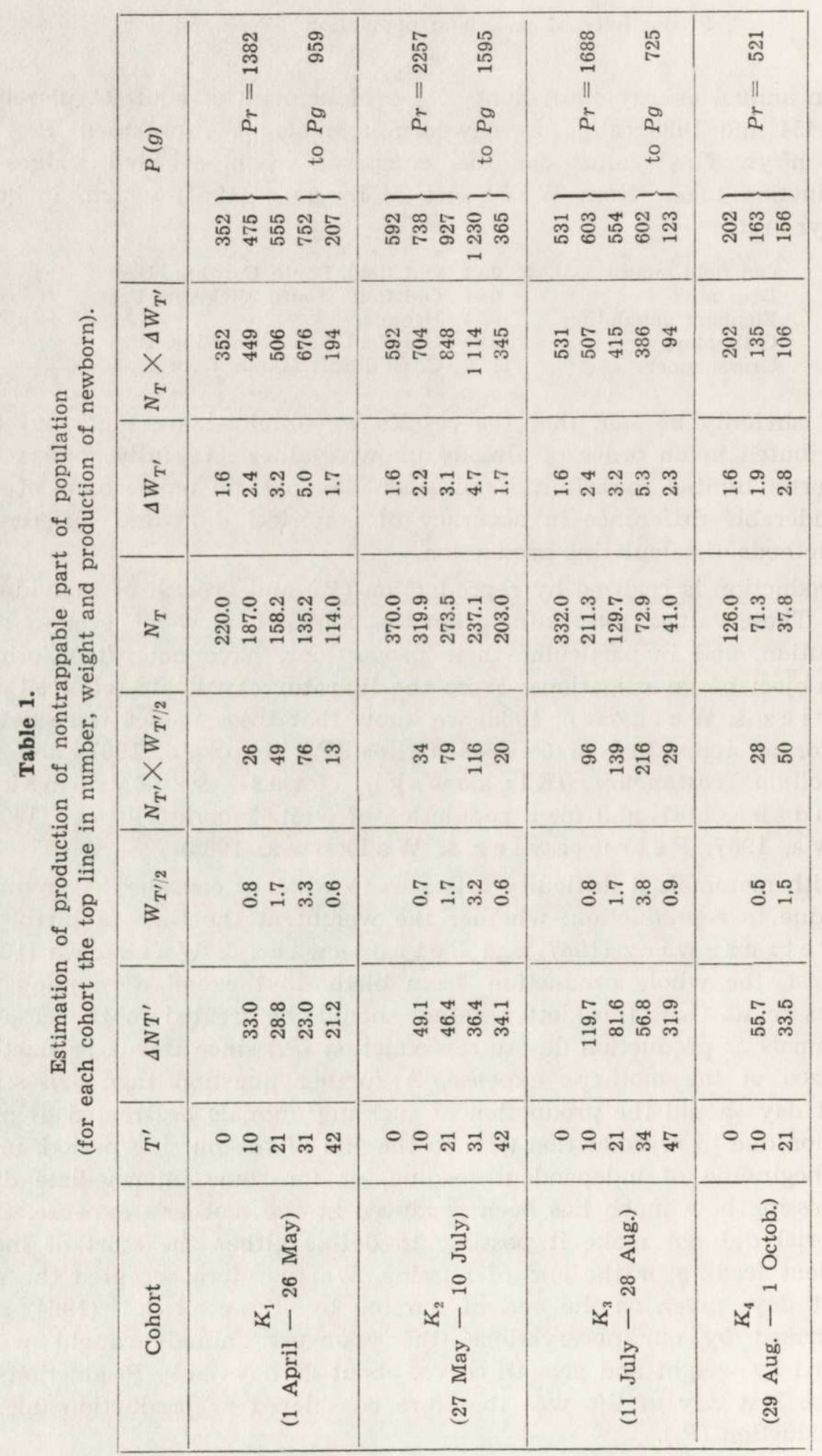




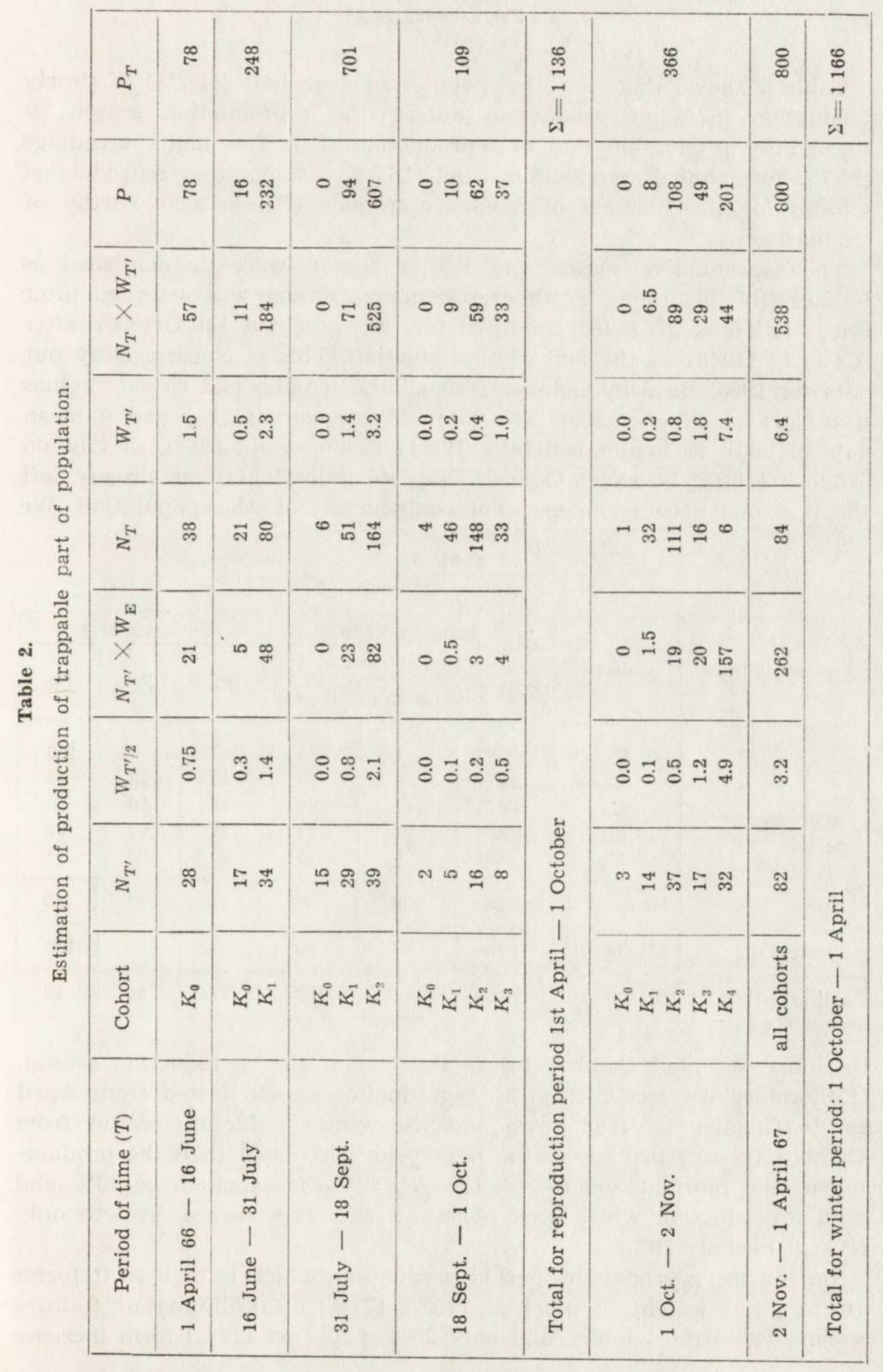


Table 3 shows that for the population over half $(51.2 \%)$ of yearly production ( $57 \%$ of production during the reproduction season) is formed by production due to reproduction $\left(P_{r}\right)$. The high percentage $(14.7 \%$ of annual production, and $16.3 \%$ during the reproduction season) for the biomass of newborn animals $\left(P_{b}\right)$ is also worthy of emphasis.

The reproductive season and winter season were distinguished as follows: the beginning of the reproduction season was accepted after Bujalska et al. (1968) as April 1st. We accepted 1st October after A s dell (1946) as the end of reproduction. This is confirmed by our data for 1966, since by October 19th all the females had closed vaginas (B u jalska et al., 1968). The late autumn cohort $\left(K_{4}\right)$ had a mean date of birth as September 10th (B ujalska et al., 1968), that is, on October 1st (to be exact October 2nd) its individuals had already left the nest and become independent components of the population. We

Table 3.

Per cent of production.

\begin{tabular}{|c|c|c|c|c|c|c|c|}
\hline \multirow{3}{*}{ Period of time } & \multirow{3}{*}{ Cohort } & \multicolumn{3}{|c|}{ Production in: } & \multicolumn{3}{|c|}{ Per cent of $P$} \\
\hline & & \multirow[b]{2}{*}{ g } & \multicolumn{2}{|c|}{ Per cent of $P$} & \multirow[b]{2}{*}{$P_{b}$} & \multirow[b]{2}{*}{$\operatorname{Pr}$} & \multirow[b]{2}{*}{$\mathrm{Pg}$} \\
\hline & & & Summer & All year & & & \\
\hline \multirow{6}{*}{$\begin{array}{l}\text { Reproductive } \\
\text { period }\end{array}$} & $K_{0}$ & 94 & 1 & 1 & - & - & 100 \\
\hline & $K_{1}$ & 2677 & 26 & 23 & 13 & 52 & 48 \\
\hline & $K_{2}$ & 4521 & 44 & 40 & 13 & 50 & 50 \\
\hline & $K_{3}$ & 2450 & 24 & 21 & 22 & 69 & 31 \\
\hline & $K_{4}$ & 521 & 5 & 5 & 39 & 100 & - \\
\hline & Mean or $\Sigma$ & 10263 & 100 & 90 & 16 & 57 & 43 \\
\hline Winter & All cohorts & 1166 & - & 10 & - & - & 100 \\
\hline All year & All cohorts & 11429 & - & 100 & 15 & 51 & 49 \\
\hline
\end{tabular}

therefore accepted October 1st as the end of the reproduction season. If therefore we accept that the reproduction season lasted from April 1 st to October 1st (183 days) and the winter reduction season from October 1st to April 1st of the next year (182 days) then the production of the reproduction season $\left(P=P_{r}+P_{g}\right)$ is as much as $90 \%$ and winter production which took place at the expense of growth only $\left(P=P_{g}\right)$ is only $10 \%$.

During the reproduction period production, which is high as it forms $10263 \mathrm{~g}$ live weight, as much as $7759 \mathrm{~g}(77 \%)$ form elimination (failure to survive to the winter), and only $2504 \mathrm{~g}$ live wt ( $23 \%$ ) form increase 
in population biomass, $A B$ (Fig. 2). During the winter period elimination is higher than the small amount of production (2977 versus 1166), that is, elimination, forming $256 \%$ of production, not only absorbs the whole production but part of the initial biomass as well. Increase in individual weight does not cover elimination and we have an negative biomass change $(\triangle B=-1811)$ (Fig. 2).
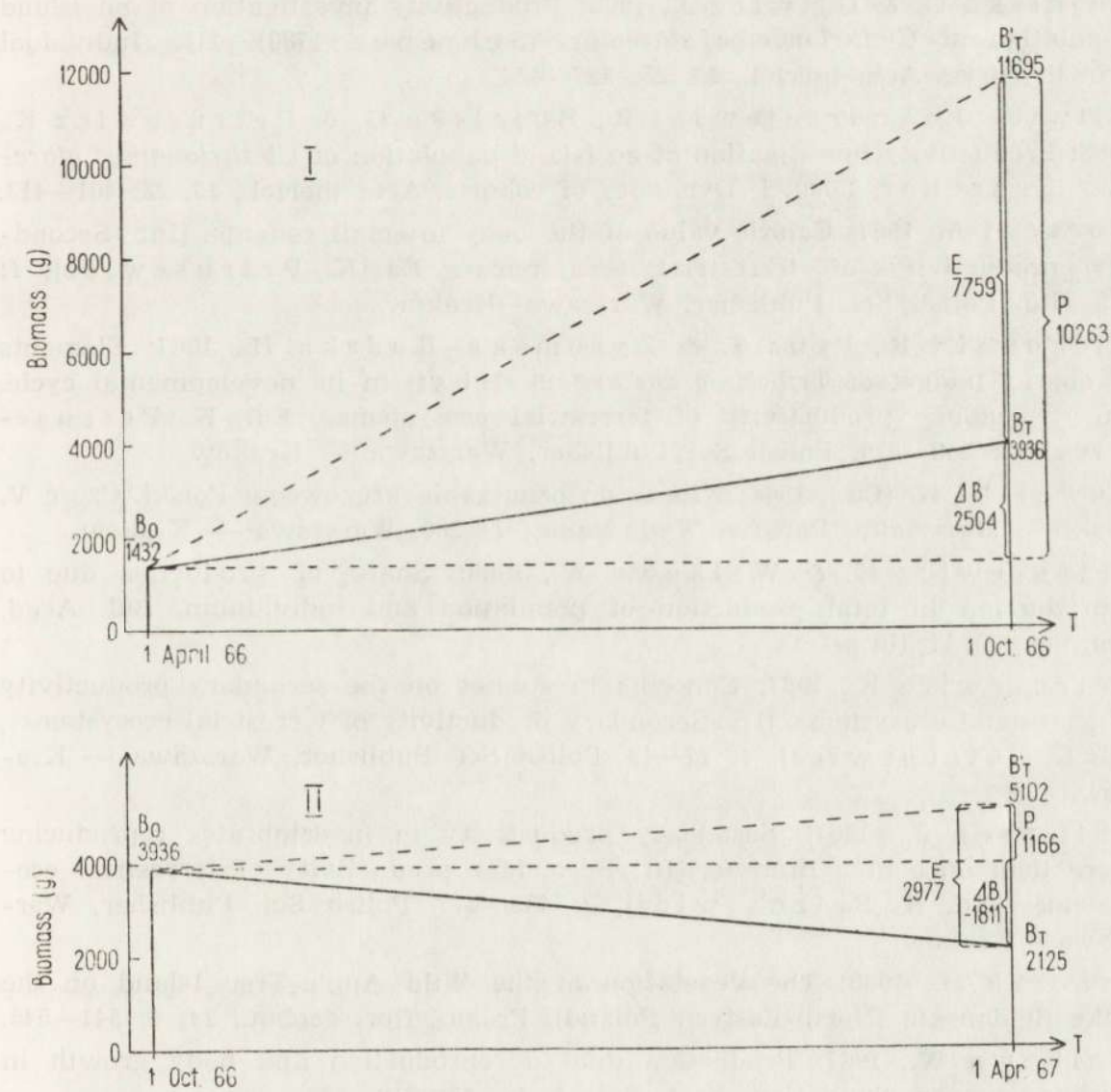

Fig. 2. Comparison of production ( $E$ - elimination and $B-$ changes in biomass) for a population of Clethrionomys glareolus during the reproductive period (I) and during period of winter reduction (II).

As far as productivity of the cohorts is concerned $K_{2}$ takes the first place during the reproductive season $(44 \%$ of the production of the reproduction season) and most certainly must also (judging by numbers) have played the greatest part in production during the winter period. Next in order was the early spring cohort $K_{1}$ and early autumn $K_{3}$. 


\section{REFERENCES}

1. Ade11 S. A., 1946: Patterns of mammalian reproduction. Comstock: 1-437, Ithaca, New York.

2. Bujalska G., Andrzejewski R. \& Petrusewicz K., 1968: Productivity investigation of island population of Clethrionomys gloreolus ( $\mathrm{S} \mathrm{c} \mathrm{h} \mathrm{r} \mathrm{e-}$ b e r, 1780). II. Reproduction. Acta theriol., 13, 24: 415-425.

3. Bujalska G. \& Gliwicz J., 1968: Productivity investigation of an island population of Clethrionomys glareolus ( $\mathrm{S} \mathrm{chreber}, 1780$ ). III. Individual growth curve. Acta theriol., 13, 25: 427-433.

4. Gliwicz J., Andrzejewski R., Bujalska G. \& Petrusewicz K., 1968: Productivity investigation of an island population of Clethrionomys glareolus (S chreber, 1780). I. Dynamics of cohorts. Acta theriol., 13, 23: 401-413.

5. Górecki A., 1967: Caloric value of the body in small rodents. [In: „Secondary productivity of terrestrial ecosystems", Ed. K. Petrusewicz], 1: 315-319. Polish Sci. Publisher. Warszawa-Kraków.

6. Klekowski R., Prus T. \& Żyromska-Rudzka H., 1967: Elements of energy budget of Tribolium castaneum ( $\mathrm{H} \mathrm{b} \mathrm{s}$ ) in its developmental cycle. [In "Secondary productivity of terrestrial ecosystems", Ed. K. Petrusewi c z], 2: 859-879. Polish Sci Publisher. Warszawa - Kraków.

7. Kowalski K. [Ed.], 1964: Klucze do oznaczania kręgowców Polski. Część V. Ssaki - Mammalia. Państw. Wyd. Nauk.; 1-280. Warszawa - Kraków.

8. Petrusewicz K. \& Walkowa W., 1968: Share of production due to reproduction in total production of population and individuum. Bul. Acad. Pol. Sci., Cl. II, (in print).

9. Petrusewicz K., 1967: Concepts in studies on the secondary productivity of terrestrial ecosystems. [In »Secondary productivity of terrestrial ecosystems Ed. K. Petrusewicz], 1: 17-49. Polish Sci. Publisher, Warszawa - Kraków.

10. Philipson J., 1967: Secondary productivity in invertebrates reproducing more than once in a lifetime. [In "Secondary productivity of terrestrial ecosystems«, Ed. K. Petrusewicz], 2: 459-475. Polish Sci. Publisher, Warszawa-Kraków.

11. Traczyk H., 1965: The vegetation of the Wild Apple-Tree Island on the Lake Bełdańskie (North-Eastern Poland). Fragm. flor. geobot., 11, 4: 541-545.

12. W a lkowa W., 1967: Production due to reproduction and body growth in confined mouse population. Ecol. Pol. A 15, 45: 819-822.

13. W i e gert R. G. \& Evans F. C., 1967: Investigations of secondary productivity in grasslands. [In "Secondary productivity of terrestrial ecosystems", Ed. K. Petrusewicz], 2: 499-518, Polish Sci. Publisher, Warszawa - Kraków.

Received, April 30, 1968.

Institute of Ecology,

Polish Academy of Sciences,

Warszawa, Nowy Świat 72. 
Kazimierz PETRUSEWICZ, Roman ANDRZEJEWSKI, Gabriela BUJALSKA i Joanna GLIWICZ

\section{BADANIA NAD PRODUKTYWNOSCIĄ WYSPOWEJ POPULACJI CLETHRIONOMYS GLAREOLUS (S C HREB E R, 1780). IV. PRODUKCJA}

\section{Streszczenie}

Przeprowadzono siedmiokrotną kontrolę stanu liczebności (i biomasy) populacji C. glareolus na weyspie na jez. Bełdany. Analizy zmian liczebności i ciężaru (Ryc.

1) dokonano dla 5 grup wiekowych - kohort $K_{0}-K_{4}$ (G liwicz et al., 1968).

Produkcję osobników od momentu urodzenia do pierwszego złowienia została oceniona w oparciu o znajomość liczby urodzonych (B ujalska et al., 1968) zakładając wykładniczy charakter krzywej przeżycia do momentu pierwszego złowienia (Tabela 1).

Produkcję osobników łowionych oparto o dane empiryczne (Tabela 2). Przyrost ciężaru osobników obliczono w oparciu o krzywe wzrostu zawarte w pracy B ujalskiej i Gliwicz (1968).

Produkcja całej populacji w okresie roku jest sumą produkcji kohort w kolejnych odcinkach czasu obliczoną wg wzoru:

$$
P_{T}=\sum_{i=1}^{i=K}\left(\Delta N_{T^{\prime}} \cdot \Delta W_{T^{\prime} / 2}+N_{T} \cdot \Delta W\right) \text {. }
$$

Wartość produkcji dla całego roku wynosiła $11429 \mathrm{~g} /$ live wt/4 ha/yr. Produkcja w sezonie rozrodczym (1.IV. - 1.X.) wynosiła $10263 \mathrm{~g} \mathrm{i} \mathrm{w} \mathrm{okresie} \mathrm{zimy} \mathrm{(1.X.} \mathrm{-}$ 1.IV.) $1166 \mathrm{~g}$. Stosunek $P_{r}-$ produkcji realizowanej kosztem matki (do 21 dnia życia) do $P_{q}$ - zrealizowanej $\mathrm{w}$ okresie samodzielnego życia osobnika wynosił odpowiednio $51 \%$ i $49 \%$ (Ryc. 2, Tabela 3). 